\title{
Possible neuropharmacological effects of Adenia trilobata (Roxb.) in the Swiss albino mice model
}

\author{
Md. Arfin Ibn Aziz ${ }^{1,2+}$, Niloy Barua ${ }^{1,2+}$, Abu Montakim Tareq ${ }^{1 \dagger}$, Najmul Alam $^{1,2}$, Ranak Jahan Prova', \\ Miskatun Nur Mamun, Mohammed Aktar Sayeed', Md. Ashraf Uddin Chowdhury ${ }^{1}$ and Talha Bin Emran ${ }^{4^{*}}$ (D)
}

\begin{abstract}
Background: Known colloquially as akandaphal in Bangladesh, Adenia trilobata has some traditional uses. Its leaves and stems are extracted with pure methanol (MEATL, MEATS) and fractioned by n-hexane (NFATL, NFATS). The in vivo anxiolytic activity was evaluated by elevated plus maze (EPM) testing and hole-board test (HBT), whilst the locomotor activity was examined using the open-field test (OFT) and hole-cross test $(\mathrm{HCT})$ and the antidepressant activity was assessed with the forced swimming test (FST) and the tail suspension test (TST).

Results: Regarding the anxiolytic activity, the $400-\mathrm{mg} / \mathrm{kg}$ doses of MEATL, NFATL, MEATS and NFATS exhibited maximum percentages of entry into the open arm of 33.85\%, 32.23\%, 30.06\% and $41.84 \%$, respectively, compare with the diazepam (69.33\%). During HBT, MEATL $(400 \mathrm{mg} / \mathrm{kg})$ and NFATL (400 mg/kg) demonstrated $51.67 \pm 0.88$ and $57.67 \pm 3.18$ instances of head-dipping relative to diazepam (64.33 \pm 3.16$)$, whilst the locomotor activity showed a dose-dependent reduction in square movements and number of hole crossings. During FST and TST, the NFATL $(400 \mathrm{mg} / \mathrm{kg}$ ) exhibited rates of $43.32 \%$ and $57.71 \%$ time spent immobile, whilst fluoxetine experienced rates of $54.79 \%$ and $55.74 \%$.

Conclusion: Adenia trilobata could be a potential component for the treatment of neuropharmacological defects. Further study is required.
\end{abstract}

Keywords: Adenia trilobata, Neuropharmacological effects, Anxiolytic, Locomotor, Antidepressant

\section{Background}

Traditional medicine is an essential part of ethnopharmacology and continues to promote the investigation of pharmacological activities for therapeutic uses [1]. Emerging ethnopharmacological information continually adds to the disclosures of new antinociceptive substances from plants [2]. Phytotherapy dependent on this information is

\footnotetext{
*Correspondence: talhabmb@bgctub.ac.bd; talhabmb@gmail.com ${ }^{\dagger}$ Md. Arfin Ibn Aziz, Niloy Barua and Abu Montakim Tareq contributed equally to this work.

${ }^{4}$ Department of Pharmacy, BGC Trust University Bangladesh, Chittagong 4381, Bangladesh

Full list of author information is available at the end of the article
}

additionally being used as a guide for the advancement of central nervous system depressant, sedative and anxiolytic drugs [3].

Depression is one of the five most common diseases in existence around the world. By the end of 2020, it may become the second leading cause of disability globally. Depression is ordinarily introduced as mood swings, trouble with speculation and physical problems such as migraine, disturbed rest and loss of energy $[4,5]$. Roughly $80 \%$ to $90 \%$ of the current literature suggests that depressive behaviours might be the result of anxiety symptoms [6]. The coexistence of anxiety and depression predicts poor results with a higher level of treatment obstruction than that 
with either disorder happening alone. Further, if they overlap with each other, it can complicate the diagnosis and delay treatment [7]. Moreover, anxiety and depression are common symptoms in Alzheimer's disease and the elongation of their duration and severity can lead to dementia [8]. There are several drugs useful for the treatment of depression and anxiety. Tricyclic antidepressants, monoamine oxidase inhibitors, serotonin-norepinephrine reuptake inhibitors and serotonergic antidepressants are mostly used for the treatment of depression, whereas benzodiazepines are useful due to their anti-anxiety, sedative and muscle-relaxant activities [9-12]. Though they have several beneficiary effects, these medications also lead to unfavourable impacts. As such, some researchers are focusing on medicinal plants to elucidate compounds that are similarly effective but with less side effects. As indicated by the World Health Organisation (WHO), around $75 \%$ of the total global populace depends upon traditional medicine for health care or remedies [13].

Adenia trilobata (family: Passifloraceae), colloquially known as akandaphal, is distributed in the Chittagong District, Assam, Myanmar, Pakistan and eastern and western Himalayas. According to a previous report, the leaves of this plant are useful in the treatment of headache, knee pain, snake bite and stomach trouble $[14,15]$. In our previous research, extracts of $A$. trilobata with different fractionations showed antioxidant, cytotoxicity, thrombolytic, antinociceptive and antidiarrheal activities [16].

As a follow-up, the present study assessed the anxiolytic, locomotor and antidepressant activities of methanol (MEATL, MEATS) and n-hexane (NFATL, NFATS) extracts of $A$. trilobata leaves and stems.

\section{Methods}

Chemicals

Diazepam and fluoxetine were procured from Square Pharmaceuticals Ltd., Dhaka, Bangladesh, whereas all other chemicals and reagent were of analytical grade.

\section{Animals}

Swiss albino mice of either sex (aged 6-7 weeks old and weighing $25-35 \mathrm{~g}$ ) were obtained from the appropriate source. The animals were familiarised with the laboratory conditions for 14 days at room temperature $\left(25^{\circ} \mathrm{C} \pm 2{ }^{\circ} \mathrm{C}\right)$ with a 12-h light/dark cycle with food pellets and ample water supply. For the animal experiments, all efforts were made to minimise the suffering of the animals. At the end of the observation period, all mice were euthanised using diethyl ether anaesthesia. This study was approved by the institutional animal ethical committee according to governmental guidelines under an approved reference number [17]. All sections of this report adhere to the Animal Research: Reporting of In Vivo Experiments guidelines for reporting animal research.

\section{Collection and preparation of plant materials}

The detailed extraction process of $A$. trilobata was as described in research by Barua et al. [16], whereas the fractioning of $n$-hexane extract was performed according to the protocol of Kupchan et al. [18]. The sample was stored at $4{ }^{\circ} \mathrm{C}$ until further use.

\section{Experimental design}

This study was conducted using four separate groups containing five Swiss albino mice each. The groups were stratified as the negative control (1\% Tween-80 solution) group, reference drug group and two test groups (200 and $400 \mathrm{mg} / \mathrm{kg}$ ): Meanwhile, the four test samples were the methanol extract of $A$. trilobata leaves (MEATL), n-hexane fraction of $A$. trilobata leaves (NFATL), methanol extract of $A$. trilobata stem (MEATS) and $\mathrm{n}$-hexane fraction of $A$. trilobata stem (NFATS), respectively. Fluoxetine was used to discern the antidepressant activity in a dose of $10 \mathrm{mg} / \mathrm{kg}$ body weight (b.w.) delivered via an intraperitoneal route (IP), whereas diazepam was used for the anxiolytic and locomotor activity assessments and was delivered as a dose of $1 \mathrm{mg} / \mathrm{kg}$ (b.w., IP). As a negative control, $1 \%$ Tween-80 in water was received as a dose of 10 $\mathrm{mL} / \mathrm{kg}$ (b.w.) by oral gavage.

\section{Anxiolytic activity \\ Elevated plus maze (EPM) test}

The EPM test was used to explore the anxiolytic activity of the extract of A. trilobata in Swiss albino mice. The EPM apparatus consisted of two open arms $\left(5 \times 10 \mathrm{~cm}^{2}\right)$ and two closed arms $(5 \times 10 \times$ $\left.15 \mathrm{~cm}^{3}\right)$ with a mid-point $\left(5 \times 5 \mathrm{~cm}^{2}\right)[19,20]$. Swiss albino mice of either sex were used in this study and the treatment was as described in the experimental design section. After $60 \mathrm{~min}$, each group of mice was individually placed in the midpoint of the apparatus and the numbers of entries into the open and closed arms, respectively, were counted. The study recorded for $5 \mathrm{~min}$. At the end of the experiment, the mice were euthanised using diethyl ether anaesthesia. 
\%Entry into the open arm $=\frac{\text { Number of entries in the open arm }}{\text { Number of entries in the open arm }+ \text { number of entries in the closed arm }} \times 100$

\section{Hole-board test (HBT)}

The HBT assessed the anxiolytic activity of the extract of $A$. trilobata. The device was made up of a wooden box with a size of $40 \times 40 \times 25 \mathrm{~cm}^{3}$ with 16 evenly distributed holes, each measuring $3 \mathrm{~cm}$ in diameter. The apparatus was elevated from the floor to a height of 25 $\mathrm{cm}$. The treatment of each group was as described in the experimental design section. After $30 \mathrm{~min}$ of dosing, each mouse was placed in the apparatus and we counted the number of head dips over $5 \mathrm{~min}$ and determined the latency of the first head dip [21, 22]. At the end of the experiment, the mice were euthanised using diethyl ether anaesthesia.

\section{Locomotor and exploratory activity Open field test (OFT)}

The locomotor and exploratory behaviours of the extract of A. trilobata in Swiss albino mice were previously determined by Saleem et al. [23]. The apparatus of the OFT construct used a wooden square with a wall height of $40 \mathrm{~cm}$, which was coloured in black and white sections alternatively, totalling 25 equal squares in the box. After the treatment of the groups, as described in the experimental design section, mice were placed in the apparatus and their movements for $3 \mathrm{~min}$ were assessed at 0, 30, 60, 90 and $120 \mathrm{~min}$ of observation. At the end of the experiment, the mice were euthanised using diethyl ether anaesthesia.

\section{Hole-cross test (HCT)}

The locomotor and exploratory behaviour analysis using the hole-cross apparatus was previously carried out by Takagi et al. [24]. A wooden box with dimensions of 30 $\times 20 \times 14 \mathrm{~cm}^{3}$ with a $3-\mathrm{cm}$ hole located in the centre of the box was positioned at the height of $7.5 \mathrm{~cm}$. The treatment of the group was as described in the experimental design section. After the treatment, each mouse was individually placed in the apparatus and the number of holes crossed was counted for $3 \mathrm{~min}$ at $0,30,60,90$ and $120 \mathrm{~min}$ of observation. At the end of the experiment, the mice were euthanised using diethyl ether anaesthesia.

\section{Antidepressant activity} Forced swim test (FST)

The antidepressant activity was assessed by FST according to the previously explained method of David et al.
[25]. The treatment of the groups was as described in the experimental design section. Sixty minutes after the administration of extract and reference drug mice were individually placed in a plastic apparatus measuring $25 \times$ $15 \times 25 \mathrm{~cm}^{3}$, which was filled with water $(15 \mathrm{~cm})$ with a consistent water temperature of $25^{\circ} \mathrm{C} \pm 2{ }^{\circ} \mathrm{C}$. The placement of individual mice in the apparatus was recorded for $6 \mathrm{~min}$, with the initial $2 \mathrm{~min}$ considered as the adjustment time and the remaining $4 \mathrm{~min}$ measured as the immobile time. At the end of the experiment, the mice were euthanised using diethyl ether anaesthesia. The following equation was used to calculate the percentage of inhibition of immobility:

$$
\text { Inhibition }(\%)=\frac{\mathrm{A}-\mathrm{B}}{\mathrm{A}} \times 100
$$

where $A$ is the mean immobility time of the control and $B$ is the mean immobility time of the test sample, respectively.

\section{Tail suspension test (TST)}

The TST was used to evaluate the antidepressant activity of A. trilobata extracts according to a previously explained method [26]. The treatment of the groups was as described in the experimental design section. Sixty minutes after treatment, mice were individually hung by their tails using adhesive tape positioned nearly $1 \mathrm{~cm}$ from the tip of the tail. The recoding and percentage of immobility were calculated as the TST results. At the end of the experiment, the mice were euthanised using diethyl ether anaesthesia.

\section{Statistical analysis}

The study results were expressed as mean \pm standard error of the mean, where $p<0.05, p<0.01$ and $p<$ 0.001 were considered to be statistically significant. The statistical analysis followed by one-way analysis of variance (ANOVA) (Dunnett's test), comparing the test groups to the negative control (1\% Tween-80) using GraphPad Prism version 8.4 (GraphPad Software Inc., San Diego, CA, USA).

\section{Results}

Effect of different extracts of $A$. trilobata on anxiolytic activity in the EPM test

EPM testing is mostly used to investigate anxiolytic behaviour in mice. Table 1 presents the results of EPM 
Table 1 Anxiolytic activity of different extract of A. trilobata on elevated plus-maze test

\begin{tabular}{ll}
\hline Group $(\mathbf{m g} / \mathbf{k g})$ & Entry into open arm (\%) \\
\hline Control & $30.33 \pm 0.88$ \\
Diazepam (1) & $69.33 \pm 1.15^{\mathrm{c}}$ \\
MEATL 200 & $23.97 \pm 0.88^{\text {ns }}$ \\
MEATL 400 & $33.85 \pm 1.26^{\text {ns }}$ \\
NFATL 200 & $25.48 \pm 2.95^{\text {ns }}$ \\
NFATL 400 & $32.23 \pm 2.42^{\mathrm{a}}$ \\
MEATS 200 & $22.75 \pm 0.87^{\text {ns }}$ \\
MEATS 400 & $30.06 \pm 0.88^{\text {ns }}$ \\
NFATS 200 & $23.14 \pm 2.44^{\text {ns }}$ \\
NFATS 400 & $41.84 \pm 3.19^{\mathrm{a}}$ \\
\hline
\end{tabular}

ns non-significant; MEATL methanol extract of $A$. trilobata leaves, NFATL $\mathrm{n}$ hexane fraction of $A$. trilobata leaves, MEATS methanol extract of $A$. trilobata stem, NFATS n-hexane fraction of $A$. trilobata stem

The statistical analysis followed by one-way analysis of variance (Dunnett's test) compared to the negative control (1\% Tween-80) using GraphPad Prism version 8.4

The results were expressed in mean \pm SEM (standard error mean)

${ }^{a} p<0.05$ considered as statistically significant

${ }^{c} p<0.001$ considered as statistically significant

testing, where diazepam $(1 \mathrm{mg} / \mathrm{kg})$ led to a significant degree of $(p<0.001)$ increased entry into the open arms $(69.33 \% \pm 1.15 \%)$ as compared with the negative control $(30.33 \% \pm 0.88 \%)$. The ANOVA of the $400 \mathrm{mg} / \mathrm{kg}$ dose of NFATL and NFATS similarly showed a significant degree of $(p<0.05)$ increased entry into the open arms $(32.23 \% \pm$ $2.42 \%$ and $41.84 \% \pm 3.19 \%$, respectively). In general, different extracts of $A$. trilobata triggered a significant dosedependent reduction in anxiety behaviour. Also, the other doses of $A$. trilobata extracts showed a nonsignificant $(p>$ 0.05 ) reduction in terms of entry into the open arms when compared with the negative control group.

\section{Effects of anxiolytic activity following the administration of $A$. trilobata extract during HBT}

During the HBT, the number of head dips was significantly increased in a dose-dependent manner for MEAT L, NFATL, MEATS $(400 \mathrm{mg} / \mathrm{kg})$ and NFATS $(400 \mathrm{mg} /$ $\mathrm{kg}$ ) relative to in the negative control group. A similar effect was observed following treatment with diazepam, whereas nonsignificant activity was observed for the $200-\mathrm{mg} / \mathrm{kg}$ doses of MEATS and NFATS. Furthermore, the latency for the first head dip showed significant behaviour in correlation with diazepam, whilst the outcomes of other treatments of A. trilobata had no significance. Table 2 presents the anxiolytic activity recorded during HBT.

\section{Effects of different extracts of $A$. trilobata on locomotor activity during OFT}

Locomotor activity was assessed by counting the number of square movements in the open-field apparatus at
Table 2 Anxiolytic activity of different extract of A. trilobata on hole-board test in mice

\begin{tabular}{lll}
\hline Group $(\mathbf{m g} / \mathbf{k g})$ & No. of head dipping & $\begin{array}{l}\text { Latency of first head } \\
\text { dipping (s) }\end{array}$ \\
\hline Control & $26.33 \pm 0.88$ & $8.33 \pm 0.88$ \\
Diazepam (1) & $64.33 \pm 3.16^{\mathrm{c}}$ & $2.0 \pm 0.57^{\mathrm{a}}$ \\
MEATL 200 & $39.33 \pm 2.33^{\mathrm{b}}$ & $6.33 \pm 2.40^{\mathrm{ns}}$ \\
MEATL 400 & $51.67 \pm 0.88^{\mathrm{c}}$ & $5.67 \pm 0.88^{\mathrm{ns}}$ \\
NFATL 200 & $43.0 \pm 2.89^{\mathrm{c}}$ & $5.67 \pm 1.76^{\mathrm{ns}}$ \\
NFATL 400 & $57.67 \pm 3.18^{\mathrm{c}}$ & $5.33 \pm 1.76^{\mathrm{ns}}$ \\
MEATS 200 & $31.0 \pm 1.53^{\mathrm{ns}}$ & $8.0 \pm 2.65^{\mathrm{ns}}$ \\
MEATS 400 & $40.33 \pm 2.33^{\mathrm{c}}$ & $7.0 \pm 1.53^{\mathrm{ns}}$ \\
NFATS 200 & $34.67 \pm 0.88^{\mathrm{ns}}$ & $7.53 \pm 0.33^{\mathrm{ns}}$ \\
NFATS 400 & $46.33 \pm 1.86^{\mathrm{c}}$ & $4.67 \pm 0.45^{\mathrm{ns}}$
\end{tabular}

ns non-significant, MEATL methanol extract of $A$. trilobata leaves, NFATL nhexane fraction of $A$. trilobata leaves, MEATS methanol extract of $A$. trilobata stem, NFATS n-hexane fraction of $A$. trilobata stem

The results were expressed in mean \pm SEM (standard error mean)

${ }^{a} p<0.05$ considered as statistically significant

${ }^{\mathrm{b}} p<0.01$ considered as statistically significant

${ }^{c} p<0.001$ considered as statistically significant

different interval times. In contrast, all doses of $A$. trilobata extract triggered a reduction in the movements with time. The positive control, diazepam, exposed a significant $(p<0.001)$ reduction of movements at 90 and 120 min of observation, whilst no findings of significance were observed at 0,30 or $60 \mathrm{~min}$ of observation. However, the MEATS $(200 \mathrm{mg} / \mathrm{kg})$ correlated with significant square movements at 0,30 and $120 \mathrm{~min}$ of observation. Fig. 1 presents the locomotor activity noted during OFT.

\section{Effects of different extracts of $A$. trilobata on locomotor activity during $\mathrm{HCT}$}

The locomotor activity of the A. trilobata extracts was observed by the crossing of the hole in the hole-cross apparatus. The diazepam exhibited significant numbers of $(p<0.001)$ hole crossings at $0,60,90$ and $120 \mathrm{~min}$ of observation, with significant treatment differences $(p<$ $0.01)$ relative to the negative control group noted at 30 min. Meanwhile, all doses of the A. trilobata extracts showed a dose-dependent reduction in the number of hole crossings. Fig. 2 presents the locomotor activity observed during HCT.

\section{Effects of different extracts of $A$. trilobata on depression- like behaviour during FST}

The antidepressant activity of $A$. trilobata extracts was assessed using the FST. Statistical analysis by ANOVA revealed a significant $(p<0.001)$ length of time of immobility for all treatments of $A$. trilobata and fluoxetine except MEATL $(200 \mathrm{mg} / \mathrm{kg})(p>0.05)$. The $400-\mathrm{mg} / \mathrm{kg}$ doses of MEATL, NFATL, MEATS and NFATS, respectively, triggered maximum percentages of inhibition 


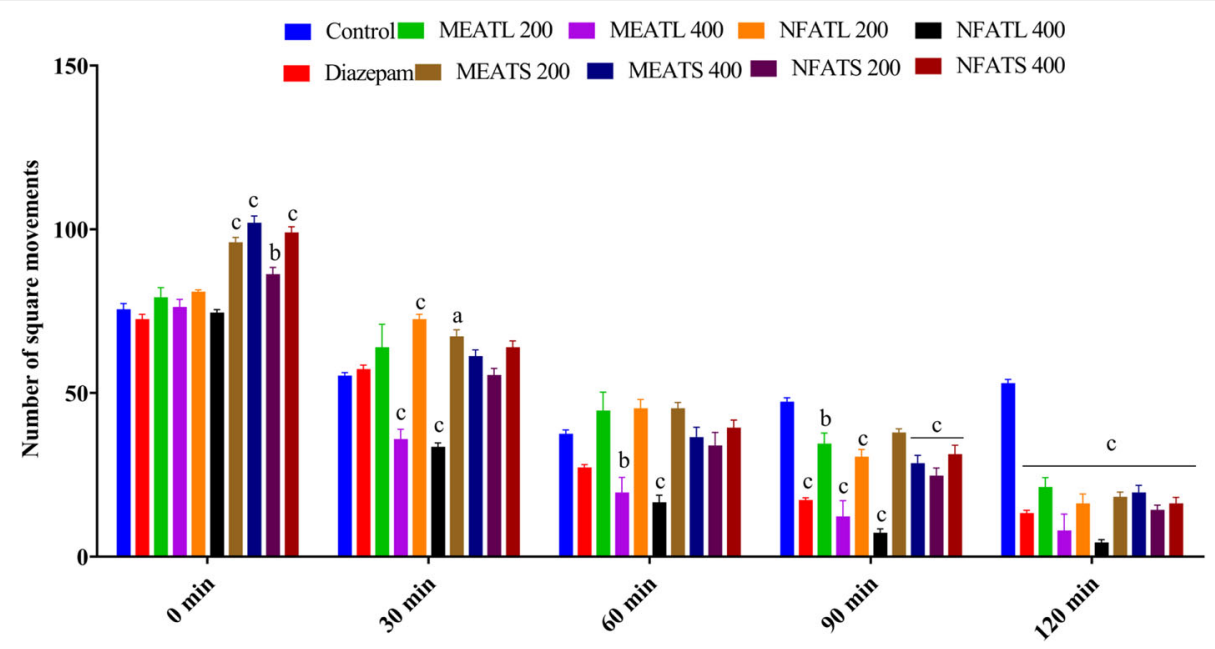

Fig. 1 Locomotor activity of different extracts of A. trilobata on open field test in mice. The results were expressed in mean \pm SEM, where ${ }^{a} p<$ $0.05,{ }^{b} p<0.01$ and ${ }^{c} p<0.001$ were considered as statistically significant. The statistical analysis followed by one-way analysis of variance (Dunnett's test) compared to the negative control (1\% Tween-80) using GraphPad Prism version 8.4. MEATL, methanol extract of $A$. trilobata leaves; NFATL, $\mathrm{n}$-hexane fraction of A. trilobata leaves; MEATS, methanol extract of A. trilobata stem; NFATS, n-hexane fraction of $A$. trilobata stem

(30.48\%, 43.32\%, 30.22\% and 39.73\%, respectively), whilst fluoxetine as the standard drug exhibited an immobility percentage of $54.79 \%$. Table 3 presents the antidepressant activity of $A$. trilobata extracts seen during FST.

\section{Effects of different extracts of $A$. trilobata on depression-}

\section{like behaviour in TST}

During the TST, the treatment of $A$. trilobata extracts and fluoxetine led to a significant $(p<0.001)$ reduction in immobility in comparison with the negative control, with the treatments showing a dose-dependent reduction pattern. The 400-mg/kg doses of MEATL, NFATL, MEATS and
NFATS exhibited maximum percentages of inhibition of $42.65 \%, 57.71 \%, 55.91 \%$ and $55.55 \%$, respectively, which was almost similar to that of the standard drug fluoxetine (55.74\%). Table 4 presents the antidepressant activity of $A$. trilobata extracts during TST.

\section{Discussion}

Complementary and alternative medicine (CAM) has become an important part of the treatment of chronic diseases. Natural products are one CAM aspect with the potential to facilitate the development of new compounds for novel therapeutic applications. Amongst

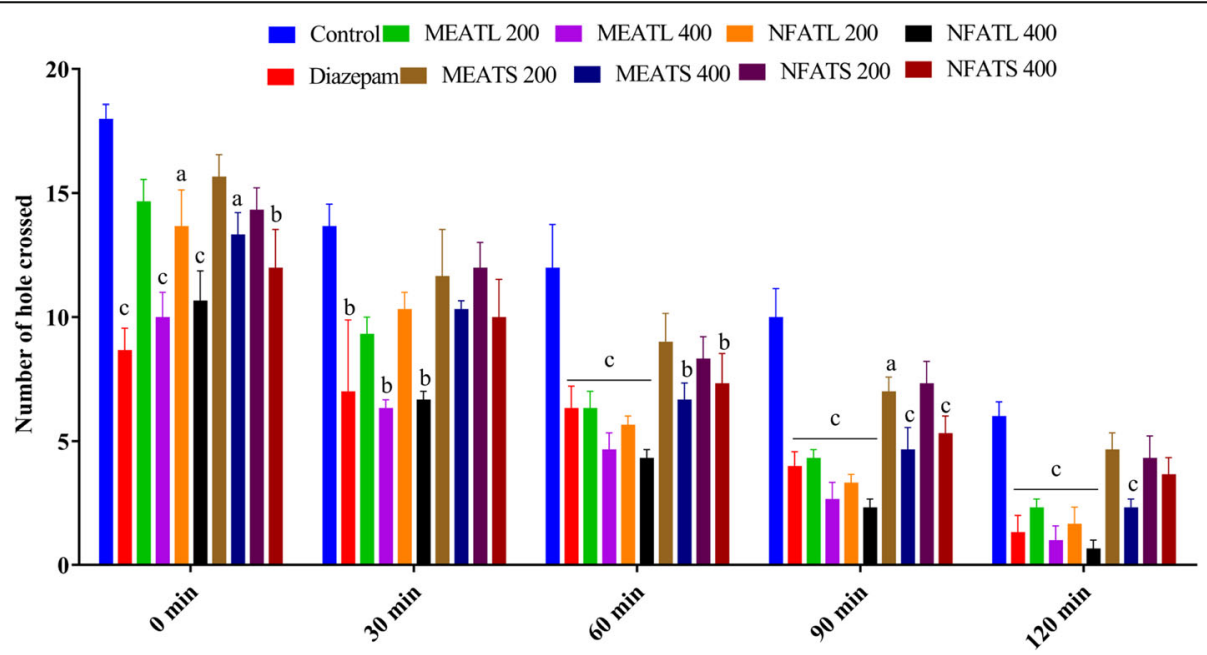

Fig. 2 Locomotor activity of different extracts of A. trilobata on hole-cross test in mice. The results were expressed in mean \pm SEM, where ${ }^{a} p<$ $0.05,{ }^{b} p<0.01$ and ${ }^{c} p<0.001$ were considered as statistically significant. The statistical analysis followed by one-way analysis of variance (Dunnett's test) compared to the negative control (1\% Tween-80) using GraphPad Prism version 8.4. MEATL, methanol extract of $A$. trilobata leaves; NFATL, n-hexane fraction of A. trilobata leaves; MEATS, methanol extract of A. trilobata stem; NFATS, $\mathrm{n}$-hexane fraction of A. trilobata stem 
Table 3 Antidepressant activity of different extracts of $A$. trilobata on forced swimming test in mice

\begin{tabular}{lll}
\hline Group $(\mathbf{m g} / \mathbf{k g})$ & Immobile time & Inhibition (\%) \\
\hline Control $(10 \mathrm{~mL} / \mathrm{kg})$ & $194.67 \pm 2.91$ & - \\
Fluoxetine $(20)$ & $88.0 \pm 1.15^{\mathrm{c}}$ & 54.79 \\
MEATL 200 & $183.0 \pm 6.51^{\mathrm{ns}}$ & 5.99 \\
MEATL 400 & $135.33 \pm 2.91^{\mathrm{c}}$ & 30.48 \\
NFATL 200 & $159.0 \pm 4.73^{\mathrm{c}}$ & 18.32 \\
NFATL 400 & $110.33 \pm 4.06^{\mathrm{c}}$ & 43.32 \\
MEATS 200 & $161.67 \pm 4.91^{\mathrm{c}}$ & 16.95 \\
MEATS 400 & $130.0 \pm 3.61^{\mathrm{c}}$ & 30.22 \\
NFATS 200 & $169.33 \pm 1.76^{\mathrm{c}}$ & 13.01 \\
NFATS 400 & $117.33 \pm 3.84^{\mathrm{c}}$ & 39.73 \\
\hline
\end{tabular}

ns non-significant, MEATL methanol extract of $A$. trilobata leaves, NFATL nhexane fraction of $A$. trilobata leaves, MEATS methanol extract of $A$. trilobata stem, NFATS n-hexane fraction of $A$. trilobata stem

The statistical analysis followed by one-way analysis of variance (Dunnett's test) compared to the negative control (1\% Tween-80) using GraphPad Prism version 8.4

The results were expressed in mean \pm SEM (standard error mean)

${ }^{c} p<0.001$ considered as statistically significant

other areas of study, the use of CAM or natural products in the treatment of neurodegenerative disease is a topic of interest for the researcher [27].

Anxiolytics properties exert their pharmacological activity by increasing $\gamma$-aminobutyric acid (GABA)-ergic neurotransmission in the brain [28]. The anxiolytic activity was assessed herein by EPM testing and the HBT. GABA receptors are directly 1 with anxiolytic effects, whilst the GABA-A receptor plays a key role in balancing neuronal inhibition and excitation [29]. In EPM

Table 4 Antidepressant activity of different extracts of $A$. trilobata on tail suspension test in mice

\begin{tabular}{lll}
\hline Group $(\mathbf{m g} / \mathbf{k g})$ & Immobile time & Inhibition (\%) \\
\hline Control $(10 \mathrm{~mL} / \mathrm{kg})$ & $186.0 \pm 1.69$ & - \\
Fluoxetine $(20)$ & $82.33 \pm 1.19^{c}$ & 55.74 \\
MEATL 200 & $158.33 \pm 4.01^{c}$ & 14.87 \\
MEATL 400 & $106.67 \pm 3.47^{c}$ & 42.65 \\
NFATL 200 & $144.0 \pm 4.36^{c}$ & 22.58 \\
NFATL 400 & $78.67 \pm 1.33^{c}$ & 57.71 \\
MEATS 200 & $113.0 \pm 2.65^{c}$ & 39.24 \\
MEATS 400 & $82.0 \pm 2.08^{c}$ & 55.91 \\
NFATS 200 & $118.33 \pm 4.91^{c}$ & 36.38 \\
NFATS 400 & $82.67 \pm 3.71^{c}$ & 55.55 \\
\hline
\end{tabular}

ns non-significant, MEATL methanol extract of $A$. trilobata leaves, NFATL nhexane fraction of $A$. trilobata leaves, MEATS methanol extract of $A$. trilobata stem, NFATS n-hexane fraction of $A$. trilobata stem

The statistical analysis followed by one-way analysis of variance (Dunnett's test) compared to the negative control (1\% Tween-80) using GraphPad Prism version 8.4

The results were expressed in mean \pm SEM (standard error mean)

${ }^{c} p<0.001$ considered as statistically significant testing, the presence of an agent with anxiolytic behaviour increases the frequency of entry into the open arms [30]. In our study, Swiss albino mice treated with different extracts of $A$. trilobata at different doses showed a significant percentage of entries into the open arms. Ultimately, the maximum percentage of entries $(p<0.05)$ was observed for the $400-\mathrm{mg} / \mathrm{kg}$ doses of NFATL and NFATS. Meanwhile, the extracts of $A$. trilobata exhibited a dose-dependent reduction in anxiety. Diazepam also triggered a significant percentage of entries into the open arms. The HBT is useful for assessing anxiety in rodent animals, whereas the increased number of head dips is considered as an anxiolytic behaviour [31, 32]. It is reported that head dipping by rodents is directly connected with the animals' emotional state [33]. In HBT, the number of head dips was significantly increased in a dose-dependent manner for MEATL, NFATL, MEATS and NFATS $(400 \mathrm{mg} / \mathrm{kg})$, with a similar observation made for diazepam as well.

To discern the impact of $A$. trilobata extracts on the central nervous system during the PFT and HCT, the numbers of square movements and holes crossed are considered as the locomotor effects, respectively [34, 35]. In our study, the decrease in locomotion triggered by the A. trilobata extracts might correlate with the antidepressant activity due to sensory neurons having an excitatory response to motor neurons and spinal interneurons in relation to muscle compaction in locomotion. In addition, GABAergic interneurons regulate this pathway by suppressing the sensory afferents at the presynaptic level [36]. Since the degree of excitability of the central nervous system is estimated by locomotion, this decrease in motor action suggests the $A$. trilobata extracts might have sedative effects.

The anxiolytic and locomotor or sedative effects of benzodiazepines (e.g. diazepam) are known to increase the activity of GABA-A. Benzodiazepines bind at the $\alpha$ subunit, which opens the chloride ion channel, leading to hyperpolarisation. The biological effects of the A. trilobata extracts might be responsible for the GABA-A receptor, benzodiazepines, and nonbenzodiazepine agents. The anxiolytic and locomotor effects of benzodiazepines might result from the activation of glycine neurotransmitters in the brain [35, 37].

The FST and TST are widely used apparatuses for assessing the effects of antidepressants in rodents. Both tests are sensitive to quantifying the impact of all kind of antidepressant drugs (e.g. selective serotonin reuptake inhibitors, monoamine oxidase inhibitors and tricyclics) [38, 39]. In our study, the $400-\mathrm{mg} / \mathrm{kg}$ extract dose led to greater reductions in immobility similar to those of the standard drug fluoxetine. In an attempt to predict a positive outcome, $A$. trilobata extracts were assessed regarding their locomotor effects; however, the $400-\mathrm{mg} / \mathrm{kg}$ 
dose of such did not demonstrate significant locomotion effects except for at a few points during the total observation time. Moreover, these reduction effects on FST and TST were thought to be due to antidepressant effects rather than locomotor-enhancing effects. According to the researcher, the GABA-A receptor is responsible for depression-like behaviours. Patients deficient in GABA as well as who show a decreased level in the GABA-A receptor might suffer from depression. As such, agents that mimic the GABAergic receptor might be effective in reducing the severity of depression [40]. The finding that $A$. trilobata extracts show antidepressant effects might be due to the activation of the GABAergic system.

\section{Conclusion}

According to the present study, A. trilobata extracts are a potential source of neuropharmacological effects and exhibit significant anxiolytic, locomotor and antidepressant activities. Notably, the anxiolytic and antidepressant effects might be mediated by the GABAergic system. However, further research is required to predict the possible mechanisms that are behind the neuropharmacological effects of $A$. trilobata.

\section{Abbreviations}

MEATL: Methanol extract of A. trilobata leaves; NFATL: $\mathrm{n}$-Hexane fraction of $A$. trilobata leaves; MEATS: Methanol extract of A. trilobata stem; NFATS: nHexane fraction of A. trilobata stem; EPM: Elevated plus maze; HBT: Holeboard test; OFT: Open field test; HCT: Hole-cross test; FST: Forced swimming; TST: Tail suspension test; b.w.: Body weight; IP: Intraperitoneal route; SEM: Standard error mean

\section{Acknowledgements}

Authors are very much thankful to the Department of Pharmacy, International Islamic University Chittagong, Bangladesh, for research facilities and other logistic supports. The authors would like to thank Cambridge Proofreading \& Editing LLC (https://proofreading.org/) for editing a draft of this manuscript.

\section{Authors' contributions}

MAIA, NB and AMT planned and designed the research. MAS, MAUC and TBE arranged the whole facilities for the research and supervised the whole research. MAIA, NB and AMT conducted the entire laboratory works with NA and RJP and MNM. MAIA, NB and AMT imparted in study design and interpreted the results putting efforts on statistical analysis with MNM and MAUC. AMT, MAIA, NB, AMT and TBE participated in the manuscript draft and has thoroughly checked and revised the manuscript for necessary changes in format, grammar and English standard. All authors read and agreed on the final version of the manuscript. The author(s) read and approved the final manuscript.

\section{Funding}

This work is conducted with the individual funding of all authors.

\section{Availability of data and materials}

The datasets used and/or analysed during the current study are available from the corresponding author on reasonable request.

\section{Ethics approval and consent to participate}

The study approved by the Institutional Animal Ethical Committee, Department of Pharmacy, International Islamic University Chittagong, Bangladesh, according to governmental guidelines under the reference of
Pharm/PND/150/20-2019. For ethical reasons, each animal was used only once and all animals were sacrificed at the end of the study.

Adenia trilobata was freshly collected from the Hajarikhil Hill tract area, Chittagong, Bangladesh, in February 2019, which was authenticated by an expert plant taxonomist Md. Anwarul Islam, Department of Botany, Jahangirnagar University, Savar, Dhaka-1342, Bangladesh, under accession number Anwar-0311.

\section{Consent for publication}

Not applicable

\section{Competing interests}

Authors declared that they have no conflict of interest.

\section{Author details}

'Department of Pharmacy, International Islamic University Chittagong, Kumira, Chittagong 4318, Bangladesh. ²Drug Discovery, GUSTO A Research Group, Chittagong 4000, Bangladesh. ${ }^{3}$ Department of Applied Chemistry and Chemical Engineering, Noakhali Science and Technology University, Sonapur, Noakhali 3814, Bangladesh. ${ }^{4}$ Department of Pharmacy, BGC Trust University Bangladesh, Chittagong 4381, Bangladesh.

Received: 6 May 2020 Accepted: 31 August 2020

Published online: 22 October 2020

\section{References}

1. Leonti M, Casu L (2013) Traditional medicines and globalization: current and future perspectives in ethnopharmacology. Front Pharmacol 4:92. https:// doi.org/10.3389/fphar.2013.00092

2. Calixto JB, Beirith A, Ferreira J, Santos AR, Filho VC, Yunes RA (2000) Naturally occurring antinociceptive substances from plants. Phytother Res 14(6):401-418. https://doi.org/10.1002/1099-1573(200009)14:6<401

3. Gurib-Fakim AJ (2006) Medicinal plants: traditions of yesterday and drugs of tomorrow. Mol Aspects Med 27(1):1-93. https://doi.org/10.1016/j.mam.2005. 07.008

4. Dwyer AV, Whitten DL, Hawrelak JA (2011) Herbal medicines, other than St. John's Wort, in the treatment of depression: a systematic review. Altern Med Rev 16(1):40-49

5. Tegegne MT, Mossie TB, Awoke AA, Assaye AM, Gebrie BT, Eshetu DA (2015) Depression and anxiety disorder among epileptic people at Amanuel Specialized Mental Hospital, Addis Ababa, Ethiopia. BMC Psychiatry 15:210. https://doi.org/10.1186/s12888-015-0589-4

6. Fißler M, Quante A (2014) A case series on the use of lavendula oil capsules in patients suffering from major depressive disorder and symptoms of psychomotor agitation, insomnia and anxiety. Complement Ther Med 22(1): 63-69. https://doi.org/10.1016/j.ctim.2013.11.008

7. Coplan JD, Aaronson CJ, Panthangi V, Kim Y (2015) Treating comorbid anxiety and depression: psychosocial and pharmacological approaches. World J Psychiatry 5(4):366-378. https://doi.org/10.5498/2Fwjp.v5.i4.366

8. García-Alberca JM, Lara JP, Berthier ML (2011) Anxiety and depression in caregivers are associated with patient and caregiver characteristics in Alzheimer's disease. Int J Psychiat Med 41(1):57-69. https://doi.org/10.2190/ pm.41.1.f

9. Dhawan K, Dhawan S, Chhabra S (2003) Attenuation of benzodiazepine dependence in mice by a tri-substituted benzoflavone moiety of Passifloro incarnata Linneaus: a non-habit forming anxiolytic. J Pharm Pharm Sci 6(2): 215-222

10. Adnan M, Chy MNU, Kamal AM, Chowdhury KAA, Rahman MA, Reza ASMA, Moniruzzaman M, Rony SR, Nasrin MS, Azad MOK, Park CH, Lim YS, Cho DH (2020) Intervention in neuropsychiatric disorders by suppressing inflammatory and oxidative stress signal and exploration of in silico studies for potential lead compounds from Holigarna caustica (Dennst.) Oken leaves. Biomolecules 10:561. https://doi.org/10.3390/biom10040561

11. Katzung BG (2012) Chapter 1: Basic principles: Introduction. Basic and clinical pharmacology. In: Lange Medical Books/McGraw-Hill, New York, 1-7, 12th edn

12. Hellión-Ibarrola M, Ibarrola $D$, Montalbetti $Y$, Kennedy M, Heinichen $O$ Campuzano M, Tortoriello J, Fernández S, Wasowski C, Marder MJ, De Lima TM, Mora S (2006) The anxiolytic-like effects of Aloysia polystachya (Griseb.) Moldenke (Verbenaceae) in mice. J Ethnopharmacol 105(3):400-408. https:// doi.org/10.1016/j.jep.2005.11.013 
13. Gilani AH, Rahman AU (2005) Trends in ethnopharmocology. J Ethnopharmacol 100(1-2):43-49. https://doi.org/10.1016/j.jep.2005.06.001

14. Ghosh A (2014) Survey of ethno-medicinal climbing plants in Andaman and Nicobar Islands. India. Int J Pharm Life Sci. 5(7):3531-3533

15. Kichu M, Malewska T, Akter K, Imchen I, Harrington D, Kohen J, Vemulpad SR, Jamie JF (2015) An ethnobotanical study of medicinal plants of Chungtia village, Nagaland. India. J Ethnopharmacol 166:5-17. https://doi. org/10.1016/j.jep.2015.02.053

16. Barua N, Ibn Aziz MA, Tareq AM, Sayeed MA, Alam N, Alam NU, Uddin MA Lyzu C, Emran TB (2020) In vivo and in vitro evaluation of pharmacological activities of Adenia trilobata (Roxb.). Biochem Biophys Rep 23:100772. https://doi.org/10.1016/j.bbrep.2020.100772

17. Zimmermann M (1983) Ethical guidelines for investigations of experimental pain in conscious animals. Pain 16(2):109-110. https://doi.org/10.1016/03043959(83)90201-4

18. Kupchan SM, Tsou G, Sigel CW (1973) Datiscacin, a novel cytotoxic cucurbitacin 20-acetate from Datisca glomerata. J Org Chem 38(7):14201421

19. Uddin M, Ali Reza ASM, Abdullah-Al-Mamun M, Kabir MS, Nasrin M, Akhter S, Arman MSI, Rahman M (2018) Antinociceptive and anxiolytic and sedative effects of methanol extract of Anisomeles indica: an experimental assessment in mice and computer aided models. Front Pharmacol 9:246. https://doi.org/10.3389/fphar.2018.00246

20. Costa de Melo N, Sánchez-Ortiz BL, Dos Santos Sampaio TI, Matias Pereira AC, Pinheiro da Silva Neto FL, Ribeiro da Silva H, Alves Soares Cruz R, Keita H, Soares Pereira AM, Tavares Carvalho JC (2019) Anxiolytic and antidepressant effects of the hydroethanolic extract from the leaves of Aloysia polystachya (Griseb.) Moldenke: A study on zebrafish (Danio rerio). Pharmaceuticals 12(3):106. https://doi.org/10.3390/ph12030106

21. Yao Y, Jia M, Wu J-G, Zhang H, Sun L-N, Chen W-S, Rahman K (2010) Anxiolytic and sedative-hypnotic activities of polygalasaponins from Polygala tenuifolia in mice. Pharm Biol 48(7):801-807. https://doi.org/10. 3109/13880200903280042

22. Babar ZM, Jaswir I, Tareq AM, Ali Reza AM, Azizi WM, Hafidz M, Ahfter F, Hasan M, Farhad S, Uddin MR, Ichwan SJ, Ahmed QU, Taher M, Mawa I (2019) In vivo anxiolytic and in vitro anti-inflammatory activities of watersoluble extract of Nigella sativa (L.) seeds. Nat Prod Res 3:1-6. https://doi. org/10.1080/14786419.2019.1667348

23. Saleem A, Hidayat MT, Jais AM, Fakurazi S, Moklas M, Sulaiman M, Amom ZJ (2011) Antidepressant-like effect of aqueous extract of Channa striatus fillet in mice models of depression. Eur Rev Med Pharmacol Sci 15(7):795-802

24. Takagi K, Watanabe M, Saito HJ (1971) Studies of the spontaneous movement of animals by the hole cross test: effect of 2-dimethylaminoethanol and its acyl esters on the central nervous system. Jpn J Pharmacol 21(6):797-810. https://doi.org/10.1016/S0021-5198(19)36179-7

25. David DJP, Renard CE, Jolliet P, Hascoët M, Bourin M (2003) Antidepressantlike effects in various mice strains in the forced swimming test. Psychopharmacol 166(4):373-382. https://doi.org/10.1007/s00213-002-1335-4

26. Steru L, Chermat R, Thierry B, Simon P (1985) The tail suspension test: a new method for screening antidepressants in mice. Psychopharmacol 85(3):367370. https://doi.org/10.1007/BF00428203

27. Parvez MK (2018) Natural or plant products for the treatment of neurological disorders: current knowledge. Curr Drug Metab 19(5):424-428. https://doi.org/10.2174/1389200218666170710190249

28. Karim N, Irshad S, Khan I, Mohammad A, Anis I, Shah MR, Khan I, Chebib MJ (2015) GABA receptor modulation and neuropharmacological activities of viscosine isolated from Dodonaea viscosa (Linn). Pharmacol Biochem Behav 136:64-72. https://doi.org/10.1016/j.pbb.2015.07.006

29. Olsen RW, Tobin AJ (1990) Molecular biology of GABAA receptors. FASEB J 4(5):1469-1480. https://doi.org/10.1096/fasebj.4.5.2155149

30. Hritcu L, Cioanca O, Hancianu M (2012) Effects of lavender oil inhalation on improving scopolamine-induced spatial memory impairment in laboratory rats. Phytomed 19(6):529-534. https://doi.org/10.1016/j.phymed.2012.02.002

31. Crawley JN (1985) Exploratory behavior models of anxiety in mice. Neurosci Biobehav Rev 9(1):37-44. https://doi.org/10.1016/0149-7634(85)90030-2

32. Takeda H, Tsuji M, Matsumiya T (1998) Changes in head-dipping behavior in the hole-board test reflect the anxiogenic and/or anxiolytic state in mice. Eur J Pharmacol 350(1):21-29

33. Ebert B, Wafford KA, Deacon S (2006) Treating insomnia: current and investigational pharmacological approaches. Pharmacol Ther. 112(3):612629. https://doi.org/10.1016/j.pharmthera.2005.04.014
34. Khan IN, Sarker MMI, Ajrin MJ (2014) Sedative and anxiolytic effects of ethanolic extract of Calotropis gigantea (Asclepiadaceae) leaves. Asian Pac J Trop Biomed 4:S400-S404. https://doi.org/10.12980/APJTB.4.2014C1147

35. Tareq AM, Sohel M, Mahmud MH, Hoque M, Reza AA, Nasrin MS, Kader FB, Emran TB (2020) Possible neuropharmacological effects of Apis cerana indica beehive in the Swiss albino mice. J Adv Biotechnol Exp Ther 3(2):128-134. https://doi.org/10.5455/jabet.2020.d117

36. Rudomin PJ (2009) In search of lost presynaptic inhibition. Exp Brain Res 196(1):139. https://doi.org/10.1007/s00221-009-1758-9

37. Shahed-Al-Mahmud M, Lina SM (2017) Evaluation of sedative and anxiolytic activities of methanol extract of leaves of Persicaria hydropiper in mice. Clin Phytosci 3(1):20. https://doi.org/10.1186/s40816-017-0056-5

38. Adebiyi $\mathrm{OE}$, Abatan MO (2013) Phytochemical and acute toxicity of ethanolic extract of Enantia chlorantha (oliv) stem bark in albino rats. Interdiscip Toxicol 6(3):145-151. https://doi.org/10.2478/intox-2013-0023

39. Cryan JF, Markou A, Lucki I (2002) Assessing antidepressant activity in rodents: recent developments and future needs. Trends Pharmacol Sci 23(5): 238-245. https://doi.org/10.1016/S0165-6147(02)02017-5

40. Möhler HJN (2012) The GABA system in anxiety and depression and its therapeutic potential. Neuropharmacol. 62(1):42-53. https://doi.org/10.1016/ j.neuropharm.2011.08.040

\section{Publisher's Note}

Springer Nature remains neutral with regard to jurisdictional claims in published maps and institutional affiliations.

\section{Submit your manuscript to a SpringerOpen ${ }^{\circ}$ journal and benefit from:}

- Convenient online submission

- Rigorous peer review

- Open access: articles freely available online

High visibility within the field

- Retaining the copyright to your article

Submit your next manuscript at $>$ springeropen.com 